\title{
INVESTIGATION ON NEW CREEP- AND OXIDATION-RESISTANT MATERIALS
}

\author{
PREISKAVA NOVEGA MATERIALA, ODPORNEGA PROTI \\ LEZENJU IN OKSIDACIJI
}

\author{
Omid Khalaj ${ }^{1}$, Bohuslav Masek ${ }^{1}$, Hana Jirkova1, Andrea Ronesova ${ }^{1}$, \\ Jiri Svoboda ${ }^{2}$ \\ ${ }^{1}$ Research Centre of Forming Technology, University of West Bohemia, Univerzitní 22, 30614 Pilsen, Czech Republic \\ 2Institute of Physics of Materials, Academy of Sciences of the Czech Republic, Zizkova 22, 61662 Brno, Czech Republic \\ khalaj@vctt.zcu.cz \\ Prejem rokopisa - received: 2014-08-25; sprejem za objavo - accepted for publication: 2014-10-02
}

doi: $10.17222 /$ mit.2014.210

\begin{abstract}
The specific mechanical property and structure of a material can be achieved by combining various types of materials and technologies. The main aim of this research is to develop new creep- and oxidation-resistant materials (ODS) (new ODS Fe-Al based alloys and ODS composites) applicable at high temperatures of up to about $1100{ }^{\circ} \mathrm{C}$. The new ODS composites consist of a ferritic Fe-Al matrix strengthened with about volume fractions $2 \%$ to $30 \%$ of $\mathrm{Al}_{2} \mathrm{O}_{3}$ particles. In order to find the optimum material structure, different oxide amounts were added to three different containers. Also, to find the influence of the temperature on the obtained structures, three processing temperatures of $(26,750$ and 1150$){ }^{\circ} \mathrm{C}$ were used with the specific deformation profile. An analysis of the structures was performed using different analytical methods such as light microscopy, scanning electron microscopy and X-ray diffraction analysis.
\end{abstract}

Keywords: ODS steel, alloys, composite, creep, Fe-Al

Posebne mehanske lastnosti in strukturo materiala je mogoče doseči s kombinacijo različnih vrst materialov in tehnologij. Glavni namen tega članka je razviti nov material, odporen proti lezenju in oksidaciji (ODS), tj. novo ODS-zlitino na osnovi $\mathrm{Fe}-\mathrm{Al}$ in ODS-kompozite, uporabne pri visokih temperaturah do $1100{ }^{\circ} \mathrm{C}$. Novi ODS-kompozit je sestavljen iz feritne $\mathrm{Fe}-\mathrm{Al}$-osnove, ojačane z okrog volumenskim deležem od $2 \%$ do $30 \%$ delcev $\mathrm{Al}_{2} \mathrm{O}_{3}$. Da bi dobili optimalno strukturo materiala, je bil v tri vsebnike primešan različen delež oksida. Za ugotovitev vpliva temperature na dobljeno strukturo so bile uporabljene tri temperature izdelave $(26,750$ in 1150$){ }^{\circ} \mathrm{C}$ s posebnim profilom deformacije. Analiza strukture je bila izvršena $\mathrm{z}$ različnimi metodami, kot so svetlobna mikroskopija, vrstična elektronska mikroskopija in rentgenska difrakcija.

Ključne besede: ODS-jeklo, zlitine, kompozit, lezenje, Fe-Al

\section{INTRODUCTION}

A new unconventional structure with specific mechanical and physical properties and new application possibilities in some areas of the industry can be obtained, using the conventional materials, with innovative technological techniques. One of these techniques includes a combination of powder metallurgy with the processing of materials in the semi-solid state or a creation of a microstructure consisting of a metal matrix and dispersed stable particles in order to develop a new material resistant to the high-temperature creep. For making intricately shaped components from such materials, represented by oxide-dispersion-strengthened (ODS) alloys, new processes must be found to allow near-net-shape products to be manufactured in a simple and rapid manner. The ODS alloys are of interest mainly because of their outstanding microstructural stability that is also the basis for superior creep properties.

The ODS alloys that were commercially produced at the end of the $20^{\text {th }}$ Century and at the beginning of the $21^{\text {st }}$ Century include MA 956 or MA $957^{1}$, PM 2000 or PM 2010², ODM alloys ${ }^{3}$ and 1 DK or $1 D^{4}$ with a ferritic matrix, ODS Eurofer steel with a tempered ferriticmartensitic matrix ${ }^{5}$ and austenitic Ni-ODS PM 1000 or Ni-ODS PM $3030^{6}$. The volume fraction of dispersed spherical oxides (usually $\mathrm{Y}_{2} \mathrm{O}_{3}$ ) is typically below $1 \%$ and the oxides typically have the mean size of 5-30 nm. Because of a lower diffusion coefficient, austenitic ODS alloys show a better creep resistance for the same oxide volume fraction and contain minimum chromium and/or aluminium contents to guarantee a sufficient oxidation resistance. However, the resistance to the coarsening of the oxides (and, thus, the stability of the creep properties) is due to the solubility of oxygen in the matrix and its diffusion coefficient ${ }^{7}$; this factor is more advantageous for the ferritic ODS alloys. This is probably the reason why the application of the ferritic ODS steels is the dominant one. The excellent creep properties of the ODS alloys are due to an attractive interaction of dislocations with oxides described in the well-known model by Rösler and $\mathrm{Arzt}^{8}$. Creep usually exhibits the threshold stress, which correlates well with the Orowan theory according to which, at a given temperature, the threshold stress is inversely proportional to the distance of the oxides. Thus, any coarsening of the oxides causes a 
degradation of the creep properties. The typical creep strength of the ferritic ODS alloys is estimated, in the available literature, to be 60 (40) $\mathrm{MPa}$ for coarse-grained structures and 20 (6) MPa for fine-grained structures at $1000(1100){ }^{\circ} \mathrm{C}^{9}$. New ODS ferritic steels are currently in development at Oak Ridge National Laboratories ${ }^{10-13}$. Sufficient amounts of $\mathrm{Al}$ and/or $\mathrm{Cr}$ in the ODS alloys are crucial for their oxidation resistance. ${ }^{14-16}$

On the basis of the thermomechanical and microstructure analyses, this paper presents the development of the new ODS Fe-Al based alloys and ODS composites applicable at high temperatures of up to about $1100{ }^{\circ} \mathrm{C}$. The new ODS composites consist of a ferritic Fe-Al matrix strengthened with about volume fractions from $6 \%$ to $10 \%$ of $\mathrm{Al}_{2} \mathrm{O}_{3}$ particles. The new ODS alloys and ODS composites produced with a combination of mechanical alloying and hot consolidation, are new types of materials with a promising property spectrum. The experimental programme was carried out in order to get a more detailed insight into these new groups of materials, to better understand their processing behaviour and their operational properties.

\section{EXPERIMENTAL PROCEDURE}

Mechanically alloyed powders consisting of a mass fraction $\mathrm{Fe} 10 \% \mathrm{Al}$ matrix and volume fractions from $6 \%$ to $10 \%$ of $\mathrm{Al}_{2} \mathrm{O}_{3}$ particles were deposited into a steel container which was not evacuated before the welding and was sealed by welding. The mechanically alloyed powders were prepared in a Pulverisette 6 planetary ball mill (produced by Fritsch), equipped with a steel milling container with a volume of $1 \mathrm{dm}^{3}$ filled with steel balls with a diameter of $20 \mathrm{~mm}$. The steel container with the mechanically alloyed powder was rolled by a rolling machine at the average temperature of 900 ${ }^{\circ} \mathrm{C}$ and a force of $1200 \mathrm{kN}$ (Figure 1). These experiments were performed in order to check the applicability of the semi-products prepared by mechanical alloying in the semi-solid process.

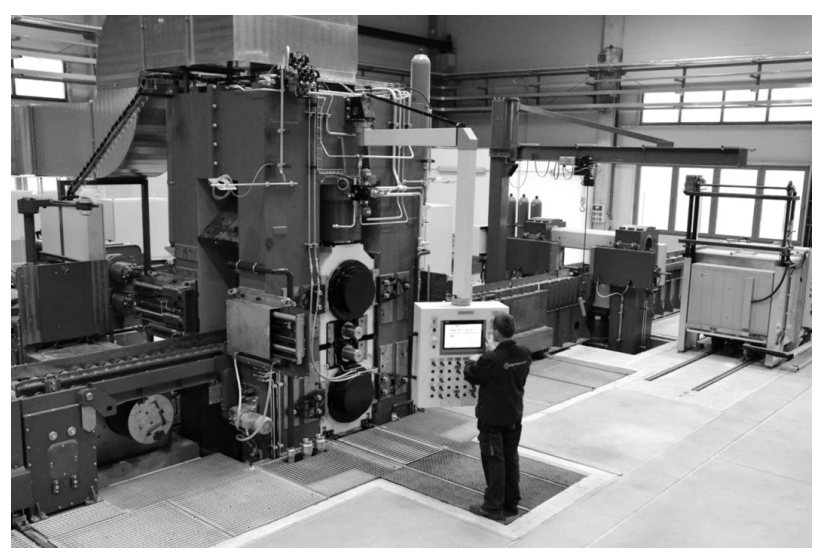

Figure 1: Hot rolling mill

Slika 1: Ogrodje za vroče valjanje
A number of metallographic methods were used to evaluate the initial powder and the resulting structures; the volume fractions of individual phases were determined using an X-ray diffraction analysis and the local chemical composition was measured using an EDX detector. The measurement was completed by determining the hardness. In order to investigate the thermomechanical treatment of the specimens, a thermomechanical simulator (Figure 2) was used, demonstrating various temperature-deformation paths necessary for finding the conditions leading to the most effective grain coarsening due to recrystallization. Multi-step thermomechanical procedures stimulating a more effective grain coarsening were also tested. Several procedures of the thermomechanical treatment were designed and carried out, differing in the number of deformation steps characterized by different strains, strain rates and temperatures. The thermomechanical simulator also allows a combination of tensile and compressive deformations, thus accumulating a high plastic deformation (and a high dislocation density) in a specimen. The experimental results of the thermomechanical simulator provided the basis for the characterization of the influence of the accumulated plastic deformation and temperature on the grain coarsening and recrystallization.

\section{TEST PROGRAMME}

The test programme was divided into preliminary tests and original tests. The preliminary tests were performed to find the appropriate specimen shapes for the heat field and the original tests were performed to investigate the thermomechanical treatment of the materials (Table 1).

Material 1 is a composite with the mass fraction $w(\mathrm{Fe})=10 \% \mathrm{Al}$ ferritic matrix and a volume fraction $\varphi\left(\mathrm{Al}_{2} \mathrm{O}_{3}\right)=10 \%$ of particles with the typical size of 300 $\mathrm{nm}$. Material 2 is an ODS alloy with the $w(\mathrm{Fe})=10 \%$ $\mathrm{Al}$ ferritic matrix and $\varphi\left(\mathrm{Al}_{2} \mathrm{O}_{3}\right)=6 \%$ of $\mathrm{Al}_{2} \mathrm{O}_{3}$ particles

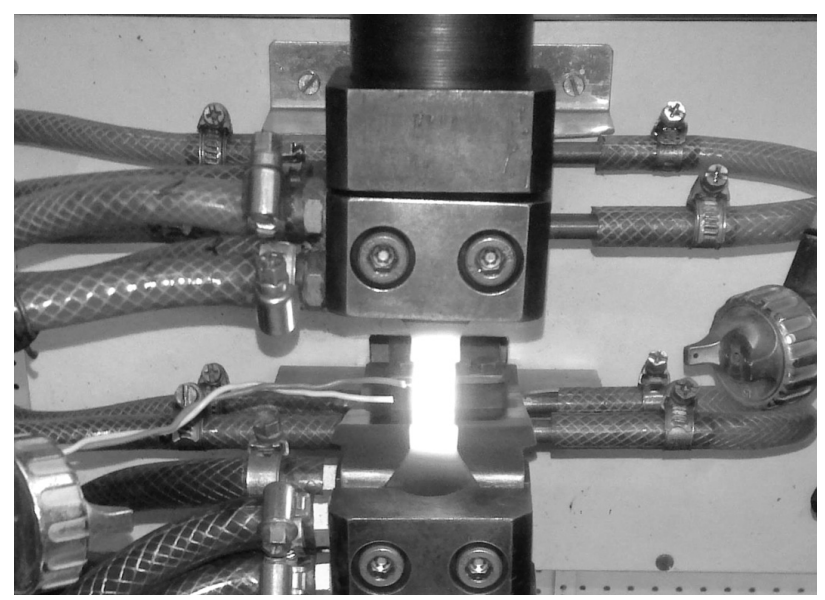

Figure 2: Thermomechanical simulator

Slika 2: Termomehanski simulator 
Table 1: Parameters of test programme

Tabela 1: Parametri programa preizkusov

\begin{tabular}{|c|c|c|c|c|c|c|}
\hline Test series & Material No. & $\begin{array}{c}\text { Specimen shape } \\
\text { No. }\end{array}$ & $\begin{array}{c}\text { Treatment } \\
\text { No. }\end{array}$ & $\begin{array}{c}\text { Maximum } \\
\text { temperature }\left({ }^{\circ} \mathrm{C}\right)\end{array}$ & $\begin{array}{c}\text { Number of } \\
\text { tests }\end{array}$ & Purpose of the tests \\
\hline A & Steel & $1,2,3,4,5,6$ & 1 & 1150 & $7^{*}$ & $\begin{array}{c}\text { To achieve the optimum } \\
\text { temperature field }\end{array}$ \\
\hline B & 1 & 5 & 2 & $\begin{array}{c}1200,1100,1000, \\
900,800,30\end{array}$ & 6 & $\begin{array}{c}\text { To check the material mechanical } \\
\text { behaviour at different temperatures }\end{array}$ \\
\hline C & 2 & 5 & 2 & $\begin{array}{c}1200,1100,1000, \\
900,800,30\end{array}$ & 6 & $\begin{array}{c}\text { To check the material mechanical } \\
\text { behaviour at different temperatures }\end{array}$ \\
\hline
\end{tabular}

* One more test to control the side temperature field

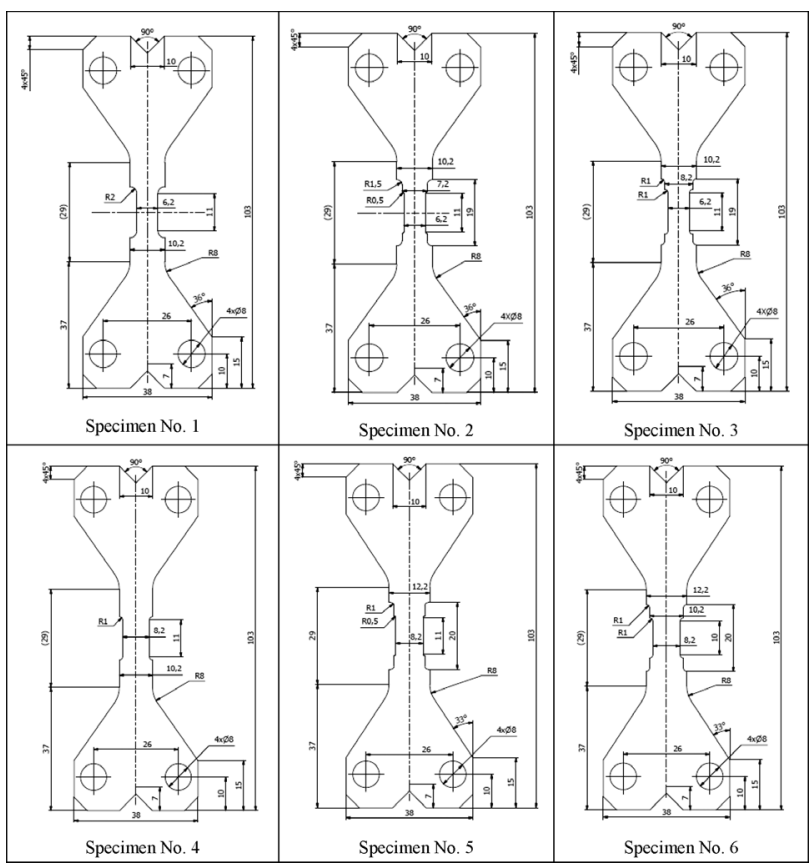

Figure 3: Six different specimen types for test series A

Slika 3: Tri različne vrste vzorcev za preizkusno serijo A

with the typical size of $50 \mathrm{~nm}$. Test series A was performed to find the optimum temperature field for the specimens. In this case, six types of different specimen shapes (Figure 3) made from steel were tested under treatment number 1 (Figure 4). In this treatment, the temperature raised to $1150{ }^{\circ} \mathrm{C}$ in $3 \mathrm{~min}$, being stable for $3 \mathrm{~min}$ and then it fell down to room temperature over 3 min.

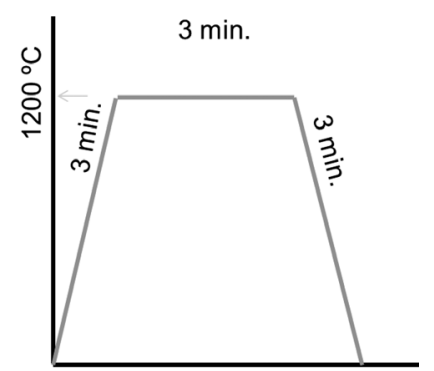

Figure 4: Treatment No. 1

Slika 4: Obdelava št. 1

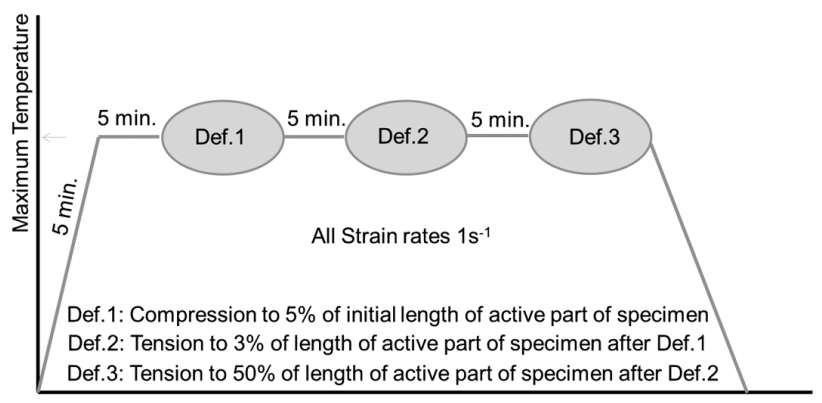

Figure 5: Treatment No. 2

Slika 5: Obdelava št. 2

Test series B was carried out to investigate the thermomechanical behaviour of Material 1 under treatment No. 2 (Figure 5), at different temperatures more precisely as the results of test series $\mathrm{C}$ showed that this material is rather sensitive to the temperature changes.

Test series $\mathrm{C}$ was performed on Material 2 (the ODS alloy) to investigate its thermomechanical behaviour under treatment No. 2 (Figure 5), at different heating temperatures.

\section{RESULTS AND DISCUSSION}

\subsection{Series $A$}

The results achieved with this series show that the homogeneity of the temperature field is more homogeneous for specimen shapes 2 and 5 than for the others. Regarding several experiences with the specimen-shape selection we decided to choose these two specimen

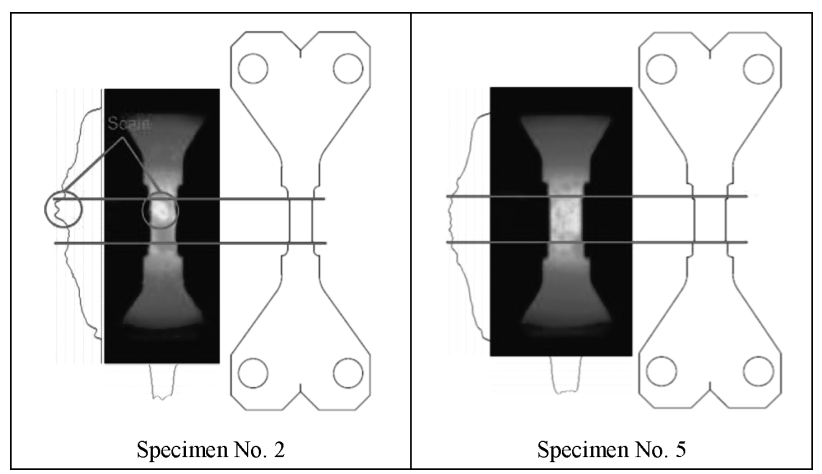

Figure 6: Thermo camera detailed results at $1150{ }^{\circ} \mathrm{C}$

Slika 6: Detajli rezultatov, dobljenih s termokamero pri $1150{ }^{\circ} \mathrm{C}$ 
shapes for the testing of Materials 1 and 2. The difference between the shapes of Specimens 2 and 5 is only in the temperature-field width. Specimen 5 has a larger cross-section in order to obtain a better sample for the microstructure investigation. Figure 6 shows the vertical and horizontal thermo-profiles of Specimens 2 and 5. The results indicate high temperature homogeneity in the middle parts of the specimens regardless of the scale.

\subsection{Series $B$ and $C$}

In the last tested series the number of the tested temperatures was increased and the temperatures used were also higher than in the previous tests. In series E Material 2 was tested. The stress-strain curves from individual deformation steps are depicted in Figures 7 to 9. Figure 7 shows the stress-strain curves for Materials 1 and 2 during a $5 \%$ compression at different temperatures. It can be seen that at high temperatures $\left(1200{ }^{\circ} \mathrm{C}\right.$ and 1100 ${ }^{\circ} \mathrm{C}$ ), both materials show the same behaviour as the maximum stress values are approximately $50 \mathrm{MPa}$ and $100 \mathrm{MPa}$ for $1200{ }^{\circ} \mathrm{C}$ and $1100{ }^{\circ} \mathrm{C}$, respectively. As the temperature decreases, Material 2 shows a more sustainable stress than Material 1. For example, at $30{ }^{\circ} \mathrm{C}$, the maximum stress for Materials 1 and 2 is $300 \mathrm{MPa}$ and $500 \mathrm{MPa}$, respectively. No fracture occurs in any tests.

The curves for a tension of $3 \%$ were also investigated (Figure 8). It can be seen that at high temperatures
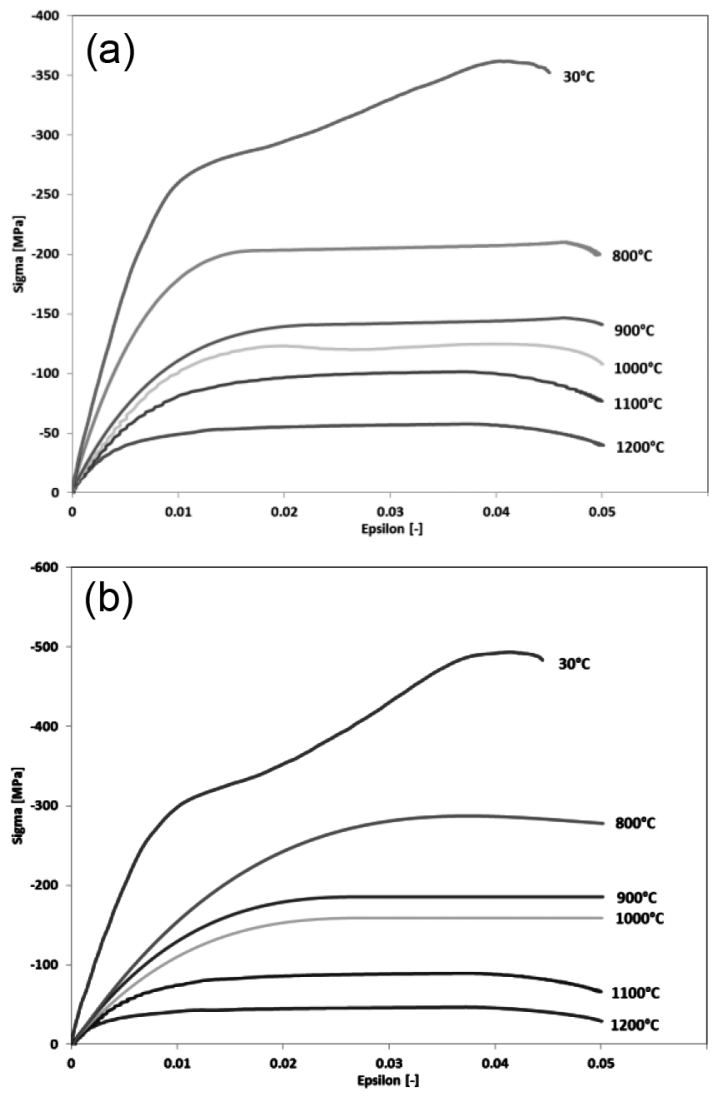

Figure 7: Stress-strain curves for $5 \%$ compression

Slika 7: Krivulja napetost - raztezek pri tlačni obremenitvi $5 \%$
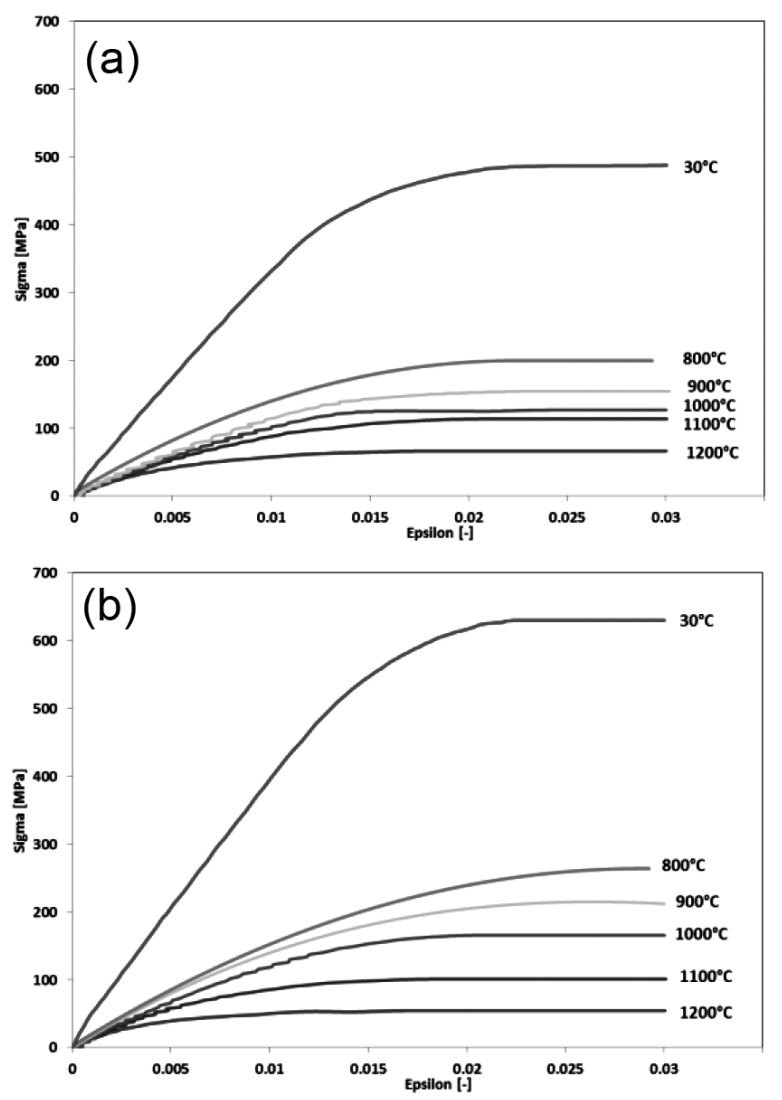

Figure 8: Stress-strain curves for $3 \%$ tension

Slika 8: Krivulja napetost - raztezek pri natezni obremenitvi $3 \%$

$\left(1200{ }^{\circ} \mathrm{C}\right.$ and $1100{ }^{\circ} \mathrm{C}$ ) both materials show the same behaviour as the maximum stress values are approximately $50 \mathrm{MPa}$ and $100 \mathrm{MPa}$ for $1200{ }^{\circ} \mathrm{C}$ and $1100{ }^{\circ} \mathrm{C}$, respectively. As the temperature decreases, Material 2 shows a more sustainable stress than Material 1. For example, at $800{ }^{\circ} \mathrm{C}$, the maximum stress for Materials 1 and 2 is $100 \mathrm{MPa}$ and $250 \mathrm{MPa}$, respectively. No fracture occurs in any tests.

Figure 9 shows the stress-strain curves of Materials 1 and 2 for a tension of $50 \%$ at different temperatures. It can be seen that at high temperatures (1200, 1100 and 1000) ${ }^{\circ} \mathrm{C}$ both materials show the same behaviour as the maximum stress values are approximately (50, 100 and 130) $\mathrm{MPa}$ for $\left(1200,1100\right.$ and 1000) ${ }^{\circ} \mathrm{C}$, respectively. As the temperature decreases, this trend also continues but with a slight difference, for example, at $800{ }^{\circ} \mathrm{C}$ the maximum stress for Material 1 is approximately 250 MPa but for Material 2 it is approximately $200 \mathrm{MPa}$. For all the specimens, fracturing occurred at a strain of $35-45 \%$, except for Material 1 at $800{ }^{\circ} \mathrm{C}$ which may due to the non-homogeneity of the material along the sheet. ${ }^{17-22}$

\subsubsection{Metallographic Analysis}

For a better understanding of the behaviour of the composite material, a metallographic analysis was performed on the fracture point of the sample that had 

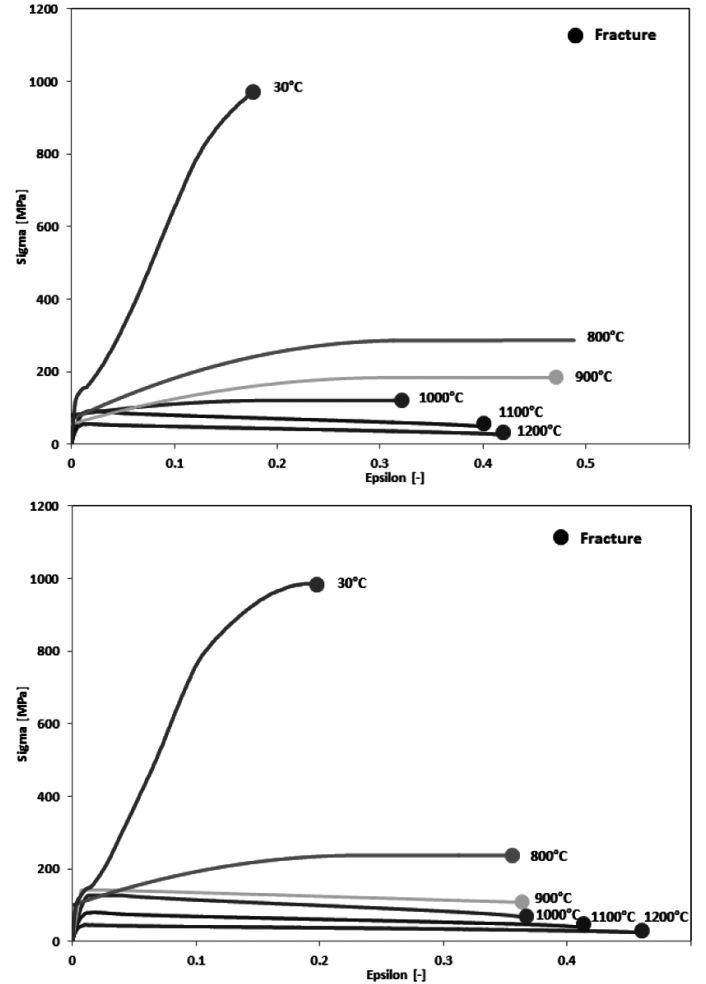

Figure 9: Stress-strain curve at $50 \%$ tension Slika 9: Krivulja napetost - raztezek pri natezni obremenitvi $50 \%$ most of the local deformation and on the other side of the sample where the deformation was zero. A fractographic analysis was also performed to describe the character of the fracture area.

\section{Material 1 - Test series B}

Figure 10 shows the structure of Material 1 (the $w(\mathrm{Fe})=10 \% \mathrm{Al}$ ferritic matrix and $\varphi\left(\mathrm{Al}_{2} \mathrm{O}_{3}\right)=10 \%$ of the particles with the typical size of $300 \mathrm{~nm}$ ) which was formed in all the cases of solid solution Fe-Al, iron aluminide and dispersed $\mathrm{Al}_{2} \mathrm{O}_{3}$ particles. Iron aluminide was mostly found around the grains of the solid solution, creating a network around the grains. Also, the particles of $\mathrm{Al}_{2} \mathrm{O}_{3}$ were, in most cases, concentrated in the area around the grains of the solid solution. With the decreasing heating temperature, which indicated a lower break temperature, a stronger impact of deformation was observed, causing an elongation of the grains.

In all the cases, the analysis of the fracture area showed a ductile mode of the fracture. Even in the case of a RT fracture there was no evidence of brittle failure. Only the grains stretched due to the deformation were seen.

\section{Material 2 - Test Series B}

In the same way a microsturctural evaluation was done for test series $\mathrm{B}$, involving Material 2 (the $w(\mathrm{Fe})=$
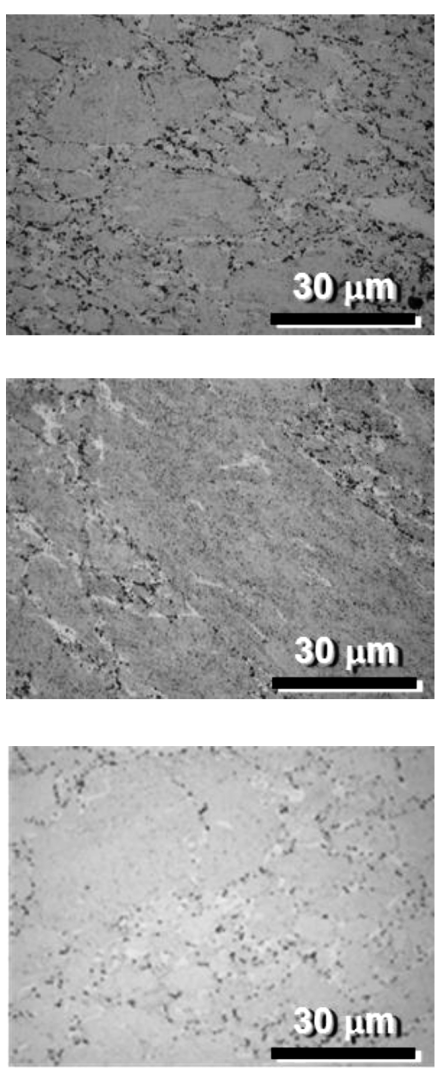

(a)
$1200{ }^{\circ} \mathrm{C}$

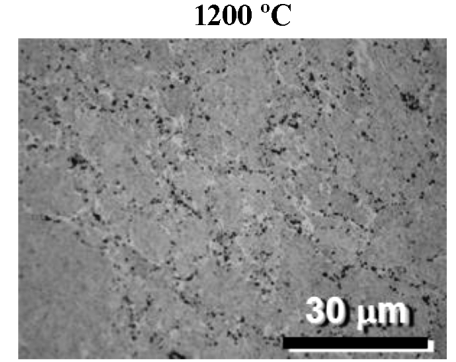

$900{ }^{\circ} \mathrm{C}$

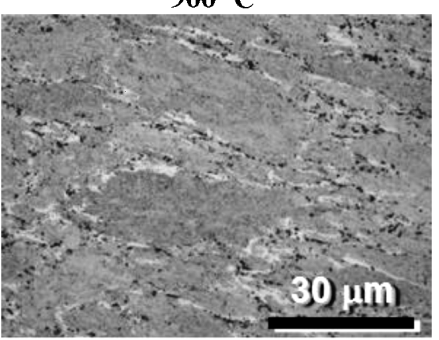

$30{ }^{\circ} \mathrm{C}$

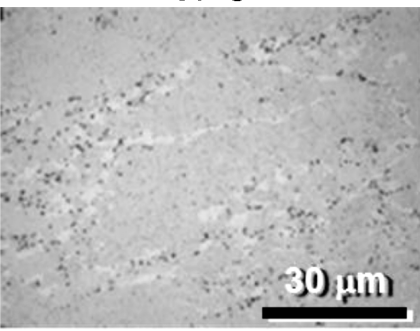

(b)
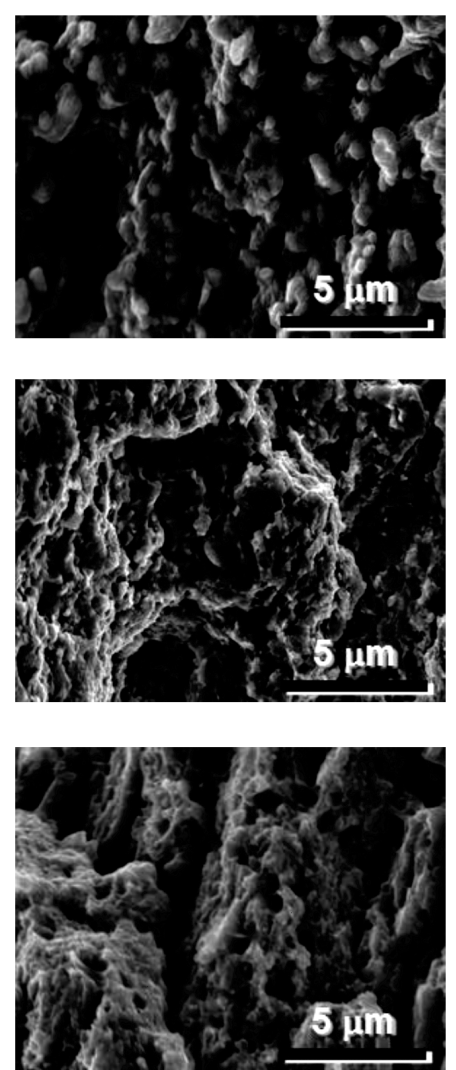

(c)

Figure 10: Microstructure of Material 1: a) area with a regular deformation, b) area close to fracture, c) fracture

Slika 10: Mikrostruktura materiala 1: a) področje z deformacijo, b) področje blizu preloma, c) prelom 

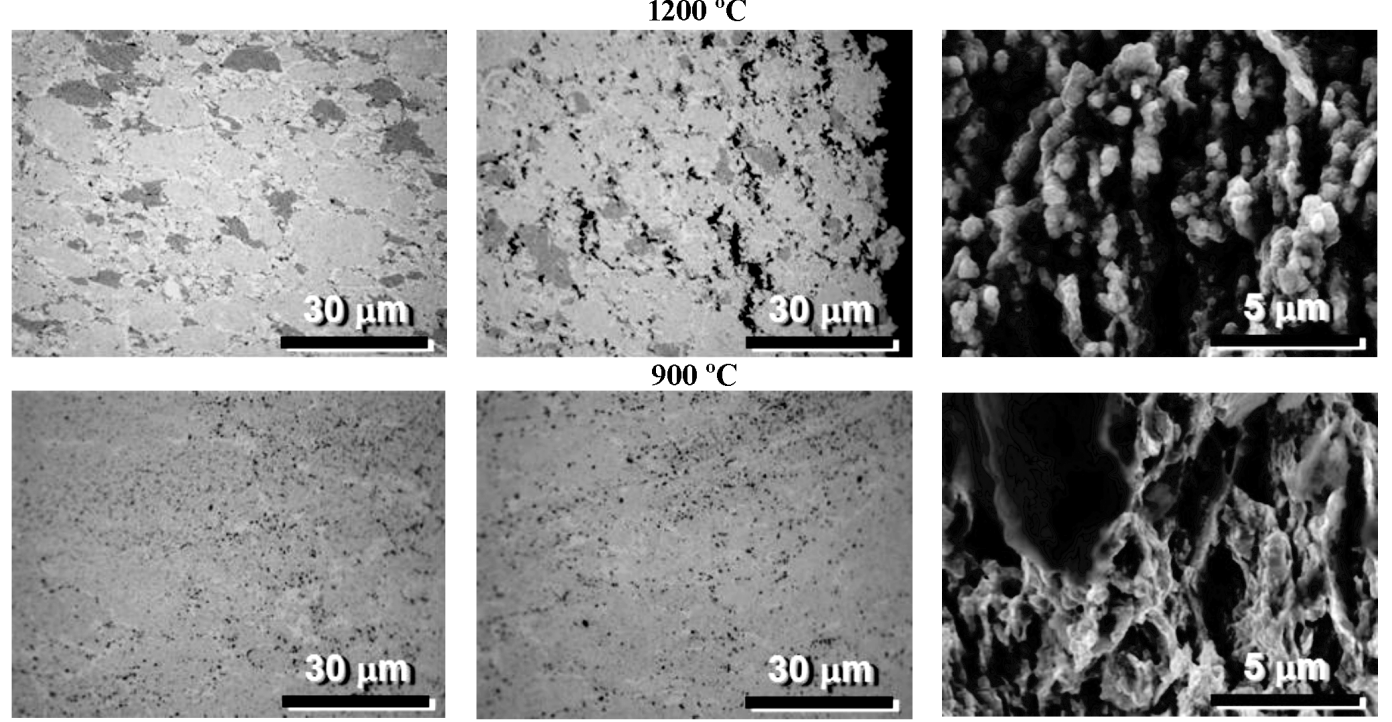

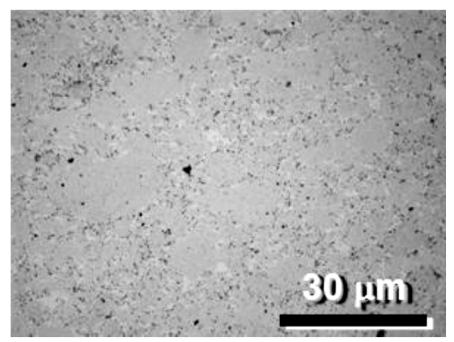

(a)

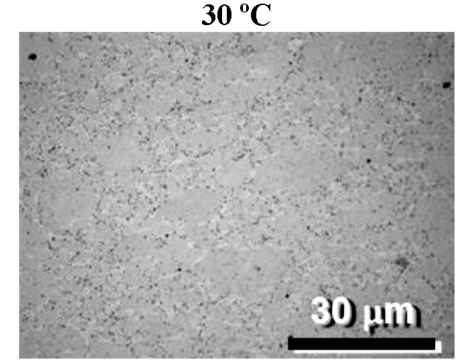

(b)

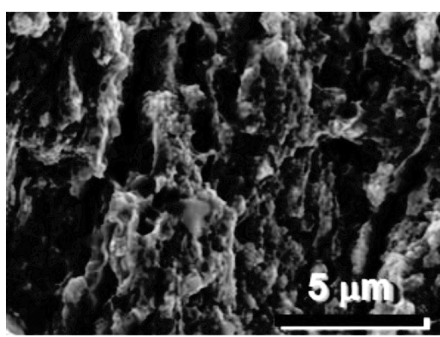

(c)

Figure 11: Microstructure of Material 2: a) area with a regular deformation, b) area close to fracture, c) fracture

Slika 11: Mikrostruktura materiala 2: a) področje z deformacijo, b) področje blizu preloma, c) prelom

$10 \% \mathrm{Al}$ ferritic matrix with $\varphi\left(\mathrm{Al}_{2} \mathrm{O}_{3}\right)=6 \%$ of the particles with the typical size of $50 \mathrm{~nm}$ ), in which there was a reduction in $\mathrm{Al}_{2} \mathrm{O}_{3}$ (Figure 11). Also, the size of the particles was reduced from $300 \mathrm{~nm}$ to $50 \mathrm{~nm}$. The structure was similar to that in the previous case. The particles of $\mathrm{Al}_{2} \mathrm{O}_{3}$ were more uniformly distributed at the lower processing temperatures and they were also found within the grains of the $\mathrm{Fe}-\mathrm{Al}$ solid solution.

\subsubsection{Hardness}

In order to compare the material stiffness values, a Vickers-hardness test was performed on both materials within HV10. As Figure 12 shows, by increasing the temperature, both materials show a lower amount of hardness caused by the changes made to the microstructures of the elements. Regarding the metallographic results, the porosity of both materials increased due to the high temperature which led to a loose interlocking of the grains.

\section{CONCLUSION}

The results of the experiments show the characterization of the thermomechanical behaviour of the newgeneration ODS alloys and composites. The difference between the two materials is in the amount and size of the oxides embedded in the ferritic matrix. The advan- tages of both materials are their low costs and creep, corrosion and oxidation resistances due to the $\mathrm{Fe}-\mathrm{Al}$ based ferritic matrix of the ODS alloys and composites. The matrix should substantially retain its uniformity during its short transition through the semi-solid state and the oxides should not coalesce. The materials of this type have the required potential for a production of intricately shaped miniature parts by mini-thixoforming. This paper shows that this particular process chain has a

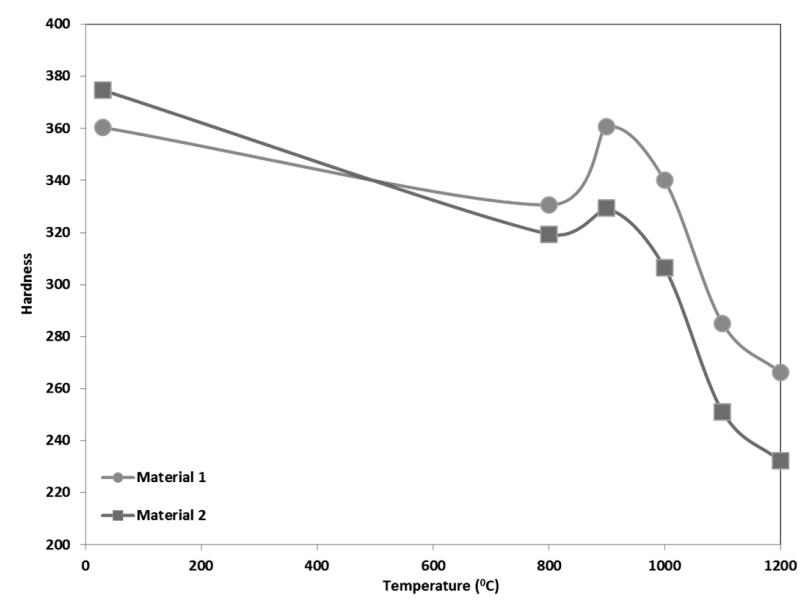

Figure 12: Vickers-hardness test (HV10)

Slika 12: Meritve trdote po Vickersu (HV10) 
large potential. Using a metallographic analysis, discontinuities and pores were detected in some areas of the samples heated at $800{ }^{\circ} \mathrm{C}$. The heating to $1000{ }^{\circ} \mathrm{C}$ and $1200{ }^{\circ} \mathrm{C}$ led to a minimizing of the discontinuities. A compact structure was formed due to the $\mathrm{Al}_{2} \mathrm{O}_{3}$ particles dispersed within the plastic matrix created by a solid solution of iron and aluminium. Follow-up research tasks will focus on shortening the heating and semi-solid processing times to inhibit the diffusion and oxide-oxide interactions, which stimulate the undesirable coalescence, the coarsening and clustering of the oxide particles.

\section{Acknowledgements}

The paper includes the results achieved within project GAČR 14-24252S "Preparation and optimization of creep resistant submicron-structured composite with $\mathrm{Fe}-\mathrm{Al}$ matrix and $\mathrm{Al}_{2} \mathrm{O}_{3}$ particles", funded from the specific resources of the state budget for research and development. The research was also supported through the projects of "EXLIZ - Excellence in human resources as a source of competitiveness" CZ.1.07/2.3.00/30.0013 and "West-Bohemian Centre of Materials and Metallurgy" CZ.1.05/2.1.00/03.0077, co-funded by the European Regional Development Fund.

\section{REFRENCES}

${ }^{1}$ Inco Alloys Limitted, Material data sheet, INCOLOY, alloy MA 956, INCOLOY, alloy MA 957, Hereford, UK, 2001

${ }^{2}$ G. Korb, M. Rühle, H. P. Martinz, Proceedings of the International Gas Turbine and Aeroengine Congress and Exposition, Orlando (FL), 1991

${ }^{3}$ B. Kazimierzak, J. M. Prignon, R. I. Fromont, Materials and Design, 13 (1992), 67-70, doi:10.1016/0261-3069(92)90109-U

${ }^{4}$ S. Ukai, M. Harada, H. Okada, M. Inoue, S. Nomura, S. Shikakura, T. Nishida, M. Fujiwara, K. Asabe, J. Nucl. Mat., 204 (1993), 74-80, doi:10.1016/0022-3115(93)90201-9
${ }^{5}$ R. Schaeublin, T. Leguey, P. Spätig, N. Baluc, M. Victoria, J. Nucl. Mat., 307-311 (2002), 778-782, doi:10.1016/S0022-3115(02) 01193-5

${ }^{6}$ Werkstoffdatenblätter der Fa. PM Hochtemperaturmetall GmbH, Reutte (A), 1992

${ }^{7}$ F. D. Fischer, J. Svoboda, P. Fratzl, Phil. Mag., 83 (2003), 10751093, doi:10.1080/0141861031000068966

${ }^{8}$ J. Rösler, E. Arzt, Acta Metall., 38 (1990), 671-683, doi:10.1016/ 0956-7151(90)90223-4

${ }^{9}$ R. Herzog, Mikrostruktur und Mechanische Eigenschaften der Eisenbasis-ODS-Legierungen PM 2000, PhD. Thesis, Forschungszentrum Jülich, Germany, 1997

${ }^{10}$ K. M. Miller, K. F. Russel, D. T. Hoelzer, J. Nucl. Mat., 351 (2006), 261-268, doi:10.1016/j.jnucmat.2006.02.004

${ }^{11}$ M. J. Alinger, G. R. Odette, D. T. Hoelzer, Acta Mater., 57 (2009), 392-406, doi:10.1016/j.actamat.2008.09.025

${ }^{12}$ M. C. Brandes, L. Kovarik, M. K. Miller, G. S. Daehm, M. J. Mills, Acta Mater., 60 (2012), 1827-1839, doi:10.1016/j.actamat.2011. 11.057

${ }^{13}$ M. C. Brandes, L. Kovarik, M. K. Miller, M. J. Mills, J. Mater. Sci., 47 (2012), 3913-3923, doi:10.1007/s10853-012-6249-x

${ }^{14}$ I. Kubena, T. Kruml, Fatigue life and microstructure of ODS steels, Eng. Fract. Mech., 103 (2013), 39-47, doi:10.1016/j.engfracmech. 2012.10.011

${ }^{15}$ I. Kubena, B. Fournier, T. Kruml, Journal of Nuclear Materials, 424 (2012), 101-108, doi:10.1016/j.jnucmat.2012.02.011

${ }^{16}$ B. Fournier, A. Steckmeyer, A. L. Rouffié, J. Malaplate, J. Garnier, M. Ratti, P. Wident, L. Ziolek, I. Tournié, V. Rabeau, J. M. Gentzbittel, T. Kruml, I. Kubena, Journal of Nuclear Materials, 430 (2012), 142-149, doi:10.1016/j.jnucmat.2012.05.048

${ }^{17}$ M. Palm, Intermetallics, 13 (2005), 1286-1295, doi:10.1016/ j.intermet.2004.10.015

${ }^{18}$ F. Stein, M. Palm, G. Sauthoff, Intermetallics, 13 (2005), 1275-1285, doi:10.1016/j.intermet.2004.08.013

${ }^{19}$ D. G. Morris, M. A. Muñoz-Morris, Materials Science and Engineering A, 462 (2007), 45-52, doi:10.1016/j.msea.2005.10.083

${ }^{20}$ S. Milenkovic, M. Palm, Intermetallics, 16 (2008), 1212-1218, doi:10.1016/j.intermet.2008.07.007

${ }^{21}$ D. G. Morris, Intermetallics, 6 (1998), 753-758, doi:10.1016/S09669795(98)00028-4

${ }^{22}$ M. A. Morris-Muñoz, Intermetallics, 7 (1999), 653-661, doi:10.1016/S0966-9795(98)00079-X 